\title{
Status of Hawks and Owls Under Manitoba's New Wildlife Act
}

Manitoba's new Wildlife Act, which came into force September, 1963, makes a further contribution toward the protection of birds of prey in Canada. Gordon Smith has reviewed the sections of the Act which provide this prctection and commented on them for the Natural History Society in Manitoba's Newsletter, No. 6, from which we quote:

"Schedule B of the Act lists the following as Protected Birds: Turkey Vulture, Accipiters (Short-winged Hawks), Buteos or Buzzard Hawks, Eagles, Harriers (Marsh Hawk), Osprey, Falcons, and Owls. In extending protection to all birds of prey the Act recognizes the futility of designating these and other predatory birds as "good" or "bad", a fact that biclogists have long since known. Naturally a landowner can protect his property from predation but a bird so killed must be reported to a conservation officer within ten days. Failure to do so is an cffence under the Act:

"In addition, other large birds such as the Raven, White Pelican and Double-crested Cormorant are protected as well as many smaller species not covcred by the Migratory Birds Convention Act. The only birds not protected are crows, magpies, cowbirds, blackbirds, starling and house (English) sparrows; most of these being econcmic pests on occasion and well able to take care of themselves.

"Sections specifically referring to birds protected under Schedule B are as follows:

"SECTION 14 reads: 'A person who hunts, kills, or captures a bird of a species or type mentioned, or to which reference is made in Schedule $B$ is guilty of an offence.'

"SECTION 55 reads: 'A person who takes or has possession of or wilfully destroys the nests or eggs of any birds mentioned in Schedule $A$ (includes Game Birds) or Schedule B without a permit to take the nests and eggs of that species or type of bird is guilty of an offence and liable, on summary conviction, to a fine not exceeding two hundred dollars or to imprison- ment of a term not exceeding one month, or to both such a fine and such imprisonment.'

"SECTION 85 deals in part with penalties impcsed upon convicticn 'of an offence relating to big game, game birds, or a bird mentioned in Schedule B', the penalty being similar to the above section."

It will be noted that Manitoba's new Act gives more complete prctection to hawks and owls than does the present Saskatchewan Game Act. The pertinent section of the latter is quoted here for comparison:

"SECTION 10 (1). Subject to subsection (2) and (3) no person shall hunt, take, shoot at, wound or kill any game bird or any other bird that is wild by nature and in a state of nature, except crows, magpies, blackbirds; grackles, English sparrows and such other birds as may be designated by the Lieutenant Governor in Council, unless he' is expressly authorized to do so by this Act or by a subsisting licence or permit issued. to him pursuant to this Act.

"(2) Notwithstanding subsection (1), a person may, without such licence or permit, hunt, take, shoot at, wound cr kill snowy. owls, greathcrned owls and goshawks during the period from the first day of November in any year to the last day of March in the following year, both dates inclusive, unless with respect to any such period or any portion of any such period the Lieutenant Governor in Council by order deçares that this subsection shall not apply during that period or pcrtion."

Saskatchewan's Act, passed in 1960, extended an important degree of protection to the birds of prey but did not fully implement the recommendation made by the Saskatchewan Natural History Society in a brief presented to the Gcvernment in 1959: "Every bird of prey (eagle, osprey, hawk and owl) should be protected, except that the owner of poultry or cther domestic animals and the members of his immediate househcld may destroy by shooting any hawk or owl which is doing real damage to the said poultry or other domestic animals." It 
will be seen that the spirit of this recommendation is fully realized in Manitoba's new Act.

The migration of the Snowy Owl in the winter into the plains of Saskatchewan coincides almost exactly with the period for which protection is not afforded it. At the Annual Meeting of the Saskatchewan Natural History Society in October, 1963, a resolution was passed asking the De- partment of Natural Resources to give protection to the Snowy Owl. Although we are informed by the Wildlife Branch (letter of January 15, $1964)$ that legislation is not being prepared this year to amend the section of the Game Act pertaining to the protecticn of hawks and owls, the progress made in Manitoba in acquiring further protection enccurages us to continue to work for similar revisions in the Saskatchewan Act.

\section{Hope for Water Birds Subjected to Detergents?}

\section{by J. R. Jowsey, Regina.}

A clear example of injury and death of water birds brought about by a concentration of waste detergents in sewage lagcons has been described by Robert W. Nero (Blue Jay, Sept., 1963, p. 91). Such undesirable conditions may be decreased soon for chemical engineers seem to be advancing fairly rapidly in the solution of the detergent foam problem in sewage (Chemical and Engineering News, March 18, 1963, p.102, and Nov. 4, 1963, p.138). However, this may or may not completely solve the problem of wetting of water birds due to "de-greasing" by detergents. Perscns interested in the welfare of our waterfowl might therefore take ncte of some of the additional features of the problem.

More rapid destruction of waste detergents by microorganisms (resulting in less foam) may be brought about as the result of the use in detergents of new raw materials which are less resistant to biodegradation (Chem. and Eng. News, Nov. 4, 1963, p. 138). If such degradation requires an appreciable time (e.g., six hours), however, birds may still be exposed to considerable hazard. The foam problem is already causing a swing away from the alkylbenzene sulfonate-based detergents because of the high resistance to the alkylbenzene sulfonates to biodegradation, and this will no doubt bring about scme reductions in the hazards to waterfowl.

Also, if the rate of reduction of foam hazard is more rapid than reduction in "de-greasing" action of detergents, then the problem of foam- ing may be resolved without any reasonable measure of protection of waterfowl being effected. The "degreasing" action on waterfowl, and the cleansing action of a soap or a detergent, may be brought about by a substance with a molecular structure which provides a satisfactory combination of radicals with an attraction for water and those with an attraction for fats and oils. It is possible, therefore, that development of a "ncn-foaming" detergent might bring about only negligible reduction in hazard to waterfowl.

In Saskatchewan the rapid increase in the number of tcwns with sewer and water services, and the many advantages of the sewage lagoon, will further increase the hazards for waterfowl if control of the "degreasing" by waste detergents is not maintained. Additional cost due to introduction of a chemical or rapid biological method of degradation in order to ensure relatively complete and rapid destruction of detergent residues may be necessary if our waterfowl are to be protected adequately from hazardous concentrations of surface-active agents in sewage lagoons.

Ed. Note: Dr. James R. Jowsey, a member of $\operatorname{rir}$ Society, is presently Science Teacher at Thom Collegiate in Regina. He has a special interest in chemistry and biology and has previouly carried out research on various problems in the nutrition of domestic animals, including birds.

R. W. Nero's article on waste detergents (Blue Jay 21:91) which is referred to in this article has been used as an illustrated feature: "Detergents - Deadly Hazard to Water Birds" in the last issue of Audubon (66:26-27), official publication of the National Audubon Society. 